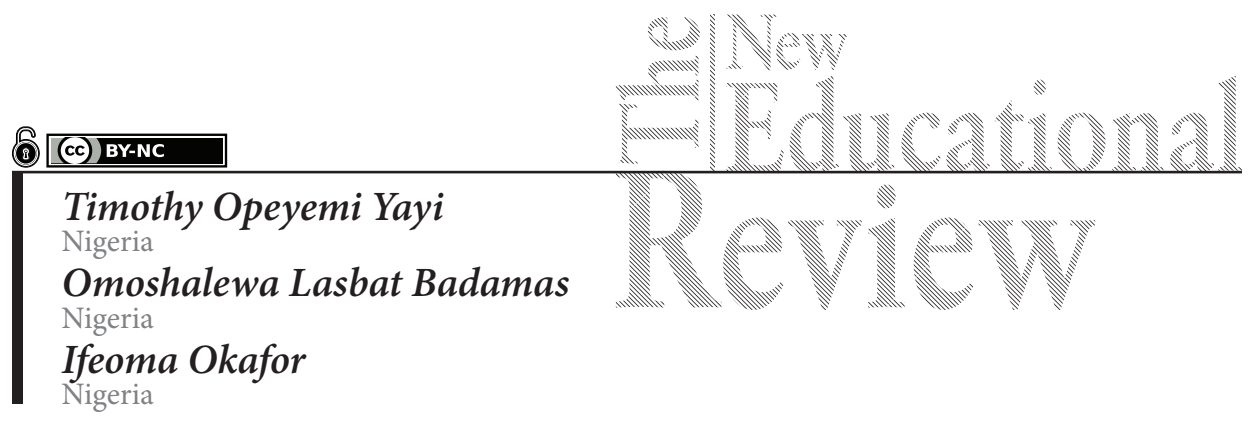

\title{
Gender Studies and Awareness of Child Rights among In-school Adolescents' in Osogbo Metropolis, Osun State, Nigeria
}

DOI: 10.15804/tner.2021.66.4.07

\begin{abstract}
The study investigated gender studies and awareness of child rights among in-school adolescents in Osogbo metropolis, Osun state, Nigeria. The study was a descriptive research method. The population for this research work consisted of upper-basic schools and students in Osun State The target population was all students in upper-basic school level 2. in Osogbo metropolis, a multi-stage sampling technique was adopted to select 350 respondents. The questionnaire instrument titled: questionnaire on childs' rights awareness was used and it was validated by experts in the Department of Social Sciences Education, University of Ilorin, Ilorin Nigeria. The reliability of the instrument was established through the test-retest method. A correlation coefficient of 0.85 was obtained, relevant data were gathered and analyzed with the appropriate statistical tools which include percentage, and a t-test was used at 0.05 level of significance. The findings of this study revealed that the awareness of in-school adolescents on child rights was low. There was a significant difference in the awareness of child's rights of male and female adolescents in favour of females. It was recommended among others that, there should be more advocacy in publicizing the Nigerian constitution and all its amendments, to make it available to schools and the general public.
\end{abstract}




\section{Introduction}

Human rights are inherent in freedom of thought, conscience, and religion; freedom of expression and association; worth of a person; equality; non-discrimination, and the dignity of the human being. They are the rights, which every human being is entitled to enjoy and to have protected. The scope of such rights includes but is not limited to fundamental principles that should be respected in the treatment of all men, women, and children. It can be found in some form in all cultures and societies. These fundamental human rights are inalienable to everyone in a given society irrespective of class, race, ethnicity, family, and educational background. Human rights were brought forth out of the four freedoms the allies adopted in post-war time (Bodnar, 2010).

In the undeveloped and developing nations, most countries have little regard for child protection. The adults and children are treated together. Instances of child rights violation and needs of children led to to this ill treatment. International guidelines on child rights have advanced spontaneously over the past years, but gaps remain in meeting those ideals (UNICEF, 2011). Child right was declared in 1959 as the U.N. Declaration of the Rights of the Child (DRC) which was upon rights that had been outlined in a League of Nations Declaration of 1924. The DRC has ten principles which are as follows: The right to equality, without distinction on account of race, religion, or national origin; the right to special protection for the child's physical, mental and social development; the right to a name and a nationality; the right to special education and treatment when a child is physically or mentally handicapped; the right to understanding and love from parents and society; the right to recreational activities and free education; the right to be among the first to receive relief in all circumstances; the right to protection against all forms of neglect, cruelty, and exploitation and the right to be brought up in a spirit of understanding, tolerance, friendship among the people, and universal brotherhood (Desmet, 2012).

Most important is the fact that the Convention on the Rights of the Child subsumes the whole spectrum of human rights ranging from civil, political, economic, to social and cultural. Also, it provides that respect and protection of all of the children's rights as the starting point for the full development of the innate and manifest capabilities of the individual in an environment of freedom, dignity, and justice. Therefore, human rights must be learned and known most especially in a democratic society. An individual must be aware of what rights he/she has; know why and how these rights should be protected. The awareness of this will go a long way to make a person seek redress if these rights are trampled upon as well as 
protect such when the need arises. The teaching and learning of human rights have been introduced into basic school curriculum as well as religious and national values curriculum which incorporated civic education, social studies, security education, Islamic religious studies, and Christian religious study as themes at the basic education in Nigeria to educate the young learner to make them acquire awareness, consciousness, thought, attitude and behaviour regarding the protection and practice of human rights(Veerman, 2010).

United Nations Declaration on Human Rights Education and Training expatiates more on what human rights education and training should be composed of; they include Education about human rights that focuses on providing knowledge and understanding of human rights norms and principles, the values that emphasize them and the mechanisms for their defense; Education through human rights, which includes learning and teaching in a way that respects the rights of both educators and learners; Education for human rights, which entails empowering persons to enjoy and exercise their rights and to respect and uphold the rights of others(United Nations, 2011).

Concerning what young people know about human rights, Bajaj (2010) found that several factors at home, in school, and the wider community affected students' keenness toward acting on what they had learned about human rights in school. According to Torney-Purta, Wilkenfeld, and Barber (2008), students were more likely to know the purpose of the universal declaration of human rights (UDHR) if they resided in countries with lesser levels of political freedom, and more probable to know the purpose of the Convention on the Rights of the Child with entitlement to special care and assistance as well as enjoying social protection and right to education for all if they lived in countries in which the national government paid attention to human rights in education-related intergovernmental dialogue.

There has been increased recognition of children as individuals having rights in the medical and mental health professions, social services, and educational systems. Attempts to increase children's rights are mainly made to guarantee that children are safe, well cared for and legally protected as well as respect the rights of others in our society. Yet, children are being exposed to many ill-treatments and are engaged in child abuse activities such as hawking on the street, child labour, and child trafficking. Several studies have examined the knowledge of the young ones on human/child rights such as a survey in Northern Ireland that found that students possessed an enormously low level of knowledge of what constituted human rights or of who was accountable for protecting those rights locally (Niens, Reilly, \& McLaughlin,2006). Plantilla (2005) study on knowledge and practice of human rights in secondary schools in Asia revealed that students commonly know 
or have heard of human rights, they do not look as if to comprehend the principles involved such as the universality principle, or do not know how they apply. Also, rural students tend to have higher consciousness or interest in human rights. Ferdinandsson and Sperl (2014) study on children's knowledge about the convention on the rights of the Child revealed that more than 80 percent of the pupils have at some point heard about the children's rights. However, the number is significantly lower for how many pupils have heard about the Convention. Furthermore, the findings revealed obvious differences where the sixth graders are often more aware of their rights than their counterparts.

Merey (2013) carried out a study on social studies pre-service teachers' attitudes towards children's rights and found out that social studies pre-service teachers' ages did not have a significant relationship with attitudes toward children's rights; social studies on pre-service teachers' attitude levels toward children's rights did not show a significant difference on the variable of gender; and social studies on pre-service teachers' levels of attitudes toward children's rights did not significantly differ on the variable of taking classes associated with children's rights. Hareket and Gülhan (2016) study on perceptions of students in primary education department related to children's rights: a comparative investigation showed that the prospective basic school teachers and teachers-trainees have similar perceptions related to child rights. However, it was revealed that the perceptions which are related to child rights of the prospective primary school teachers are more comprehensive than perceptions of the prospective pre-school teachers related to child rights. Moreover, it was revealed that both prospective teacher groups do not have adequate awareness and consciousness about child rights.

Students' knowledge about human rights may vary depending on the particular approach and its local implementation - that they have experienced, as well as on their personal and community experiences with human rights and broader public discourses about such issues(Barton, 2015). According to Torney-Purta, Wilkenfeld, and Barber (2008), students were more likely to know the purpose of the UDHR if they lived in countries with lesser levels of political freedom and more probable to know the purpose of the Convention on the Rights of the Child if they lived in countries in which the national government paid attention to human rights in education-related intergovernmental dialogue. A survey in Northern Ireland found that students possessed an enormously low level of knowledge of what constituted human rights or of who was accountable for protecting those rights locally. Also, the study revealed that students' knowledge of, and support for, human rights varied based on their religious/political community (Niens, Reilly, \& McLaughlin, 2006). 
Students commonly know or have heard of human rights, they do not look as if to comprehend the principles involved such as the universality principle or do not know how they apply. Also, rural students tend to have higher consciousness or interest in human rights. This may be due to the situation they find themselves in. Rural students tend to experience or may be suffering from conflicts, injustices, and other problems in their day-by-day lives and thus have sharper logic of what could be human rights violations (Plantilla, 2005).

The aforementioned studies are related to this study but they were done outside the country. Also, regrettably, there is relatively little empirical work dealing with young people's most especially adolescents. This is the gap this study attempts to fill.

\section{Research Questions}

1. What is the awareness level of in-school adolescents on child rights?

2. Is there any significant difference in the awareness of adolescents on child rights based on gender?

\section{Method}

The research design for this study was a descriptive study. Descriptive research is useful where it is not possible to test and measure the large number of samples needed for more quantitative types of experimentation (Picciano, 2004). The population for the study was all upper-basic school students in Osun State, Nigeria. The target population for the study was all upper-basic school II students in Osogbo Metropolis, Osun State, Nigeria. Osogbo Metropolis has two local governments. Olorunda Local Government and Osogbo local government. The two local governments have a total number of two thousand four hundred and twenty-nine $(2,429)$ students at the upper-basic school (Ministry of Education, 2019). The research advisor online indicated three hundred and thirty-three (333) respondents as the required sample size for the target population. The sampling technique that was employed was the multi-stage sampling technique. In the first stage, five schools were randomly selected from the existing schools in each local government. At the second stage, five upper basic schools II were selected. In a third stage, thirty-five (35) students were randomly selected from the schools. Finally, the total number of respondents was three hundred and fifty (350). 
A questionnaire designed by the researcher was used. The questionnaire elicited information on child rights awareness of in-school adolescents. The instrument was content and face validated by giving the draft to experts in measurement and evaluation, teachers of civic education, and some lecturers in the department of social sciences education, University of Ilorin, Ilorin for necessary comments as regards the suitability and coverage of the test items. Based on their comments, some modifications were made. Also, the test and retest method of reliability was used to determine the reliability of the instrument. The instrument was administered to a group of students who shared characteristics with the study samples. A reliability coefficient of 0.85 was obtained. Research question one was answered using mean, research question two was answered using a t-test.

\section{Result}

Table 1. Demographic Characteristics of the Respondents

\begin{tabular}{|c|c|c|}
\hline Variables & Frequency Distributions & Percentages (\%) \\
\hline \multicolumn{3}{|l|}{ Gender } \\
\hline Male & 200 & 57.1 \\
\hline Female & 150 & 42.9 \\
\hline Total & 350 & 100.0 \\
\hline
\end{tabular}

Results in Table 1 indicated that 350 respondents participated in the study out of which $57.1 \%$ were males while 42.9 were females. This shows that there were more male respondents than female respondents.

Research Question 1: What is the awareness level of in-school adolescents on child rights?

To answer research question 1, responses on the awareness of in-school adolescents on child rights were summed and analyzed. The minimum score, maximum score, and range score of the respondents were 10, 40, and 30 respectively. The range was divided by the two levels of awareness (high and low) and the cut-off was 15. Respondents with scores from 10-25 were regarded as having a low level of awareness about child rights, while respondents with scores from 26-40 were regarded as having a high level of awareness about child rights. The result of the analysis is presented in Table 2 . 
Table 2. Responses on Awareness of Child Rights

\begin{tabular}{|l|c|c|}
\hline \multicolumn{1}{|c|}{ Awareness } & Frequency & Percentage (\%) \\
\hline High & 122 & 34.9 \\
\hline Low & 228 & 65.1 \\
\hline Total & 350 & $\mathbf{1 0 0 . 0}$ \\
\hline
\end{tabular}

Results in Table 2 showed the awareness of in-school adolescents on child rights. As contained in the table, $34.9 \%$ of the sampled respondent had high awareness of child's rights, while $65.1 \%$ of the sampled respondents had low awareness of child's rights. This means that the awareness of in-school adolescents on child rights was low.

Research Question 2: Is there any significant difference in the awareness of adolescents on child rights based on gender?

Table 3. Independent t-Test on Difference in the Awareness of Child's Rights of Male and Female Adolescents

\begin{tabular}{llllllll}
\hline Gender & No & Mean & Std. & t-value & Df & p-value & Remark \\
\hline Male & 200 & 13.80 & 2.21 & & & & \\
\hline & & & 348 & 33.03 & 0.00 & Significant \\
\hline Female & 150 & 27.23 & 5.15 & & & & \\
\hline
\end{tabular}

Results in Table 4 showed at-value of 33.03 with p-value of 0.00 and the p-value is less than $0.05(0.00<0.05)$. Since 0.00 is less than 0.05 alpha level of significance, the null hypothesis was rejected. This implies that there was a significant difference in the awareness of the child's rights of male and female minors.

Summary of Findings

1. The awareness of in-school adolescents on child rights was low.

2. There was a significant difference in the awareness of child's rights of male and female adolescents in favour of females

\section{Discussion of the Findings}

The study assessed in-school minors' knowledge of child rights in Osogbo Metropolis, Osun State, Nigeria. The finding of this study revealed that the aware- 
ness of in-school adolescents on child rights was low. This means that majority of the sampled respondents had a low level of awareness about child's rights. This result is possible where there were not enough sources of knowledge on child's rights. This result supported the earlier work of Akiri (2013) who studied students' and human rights awareness in secondary schools' environment in Delta State and found that more students are not aware of their rights.

On the final note, the result of this study showed that there was a significant difference in the awareness of child's rights of male and female adolescents in favour of females. This means that gender influenced the awareness of child's rights of adolescents. This finding agrees with that of Muller (2009) who studied human rights education in German schools and post-secondary institutions and found that female students' ability to name human rights is significantly higher than that of male students. Based on the findings of this study and the discussion it was concluded that the majority of the sampled adolescents had a low level of awareness on child rights and that there was a significant difference in the awareness of child's rights of male and female adolescents in favour of females. This means that the moderating variable examined in the study determined the awareness of adolescents on child's rights.

\section{Recommendations}

The following recommendations have been put forward based on the findings of the study:

1. Students' rights should be taken into consideration in the formulation and execution of educational policies.

2. The State should seek to consciously promote fundamental human rights awareness, by making the study of subjects which contains elements of the constitution as core, especially for those in the primary and secondary level of education.

3. There should be more advocacy in publicizing the Nigerian constitution and all its amendments, so as to make it available to schools and the general public.

4. The school climate should incorporate the mechanism that will promote teaching and practice of human and child rights in our schools. 


\section{References}

Akiri, A.A. (2013). Students' and human rights awareness in secondary schools' environment in Delta State, JEP E-Journal of Education Policy, Retrieved 22, September 2019 from http:/nau.edu/coe/ejournal

Bodnar, J. (2010). The good war in American memory. Maryland: Johns Hopkins University Press.

Desmet, E. (2012). Implementing the Convention on the Rights of the Child for 'youth': who and how? The International Journal of Children's Rights, 20(1), 3-23.

Ferdinandsson, A. \& Sperl, A. (2014).Children's knowledge about the convention on the Rights of the Child: An Empirical Study Investigating Sixth and Ninth Grade Pupils in Sweden, Unpublished Bachelor Degree Project, Jonkoping University, Sweden.

Hareket, E. \& Gülhan, M. (2016). Perceptions of students in primary education department related to children's rights: A Comparative Investigation, Journal of Education and Learning, (6) 2, 41-52.

Merey, Z. (2013).Social studies pre-service teachers' attitudes towards children's rights, Journal of theory and practice in education, 9(3), 243-253

Muller, L. (2009). Human rights education in German schools and post-secondary institutions. Research in human rights education, Series, 2. Retrieved 27th, August 2019 from www.hrea.org/research.

Niens U., Reilly J. \& McLaughlin, R. (2006). The need for human rights education in Northern Ireland: A pupil survey, Journal of Peace Psychology 12(3), 251-268.

Picciano, A.G. (2004). Educational Research Primer. London :Continuum.p. 100

Plantilla, J.R. (2005). Knowledge and practice of human rights in secondary schools. Retrieved from http://www.hurights.or.jp/archives/human_rights_education_in_asian_schools

Torney-Purta, J. Wilkenfeld, B. \& Barber, C. (2008). How adolescents in 27 countries understand, support, and practice human rights? Journal of Social Issues 64(4): 857-880.

United Nations \& United Nations Educational, Scientific and Cultural Organization, (2012). Human Rights Education in Primary and Secondary School Systems: A Self-assessment Guide for Governments. New York and Geneva: UN and UNESCO.

United Nations (2011).United Nations Declaration on Human Rights Education and Training Retrievedfrom:http://daccess-dds-ny.un.org/doc/UNDOC/GEN/N11/467/04/PDF/ N1146704.pdf?OpenElement.

Veerman, P.E. (2010). The Ageing of the UN Convention on the Rights of the Child.The International Journal of Children's Rights 18(4), 585-618. 


\section{APPENDIX I}

\section{UNIVERSITY OF ILORIN DEPARTMENT OF SOCIAL SCIENCES EDUCATION QUESTIONNAIRE ON CHILDS' RIGHTS AWARENESS}

This questionnaire is prepared for my research entitled "Gender Studies and Awareness of Child Rights among In-school Adolescents' in Osogbo Metropolis, Osun State, Nigeria". Please read the below statements and tick the appropriate options from the following: Strongly Agree (SA); Agree (A); Strongly Disagree (SD); Disagree (D). Thanks in anticipations for your cooperation.

Gender: Male () Female ()

\section{Child's Right Awareness}

\begin{tabular}{rlll}
\hline S/N & ITEMS & SA A & SD D \\
\hline 1. & I have the right to live & \\
\hline 2. & I have the right to a name as well as an identity & \\
\hline 3. & I have the right to live with my parent unless it is bad for me & \\
\hline 4. & I have the right to be protected as well as care for \\
\hline 5. & I have the right to express my opinion \\
\hline 6. & I have the right to choose my religion, association as well as belief \\
\hline 7. & I have the right to education by my parents even if I am disabled, \\
& deformed, and blind. \\
\hline 8. & I have the right best health care, conducive environment to live in \\
\hline 9. & $\begin{array}{l}\text { My parents must not base my welfare on the fact that I must } \\
\text { involve myself in labour like hawking etc. }\end{array}$ \\
\hline 10. & I have the right to know my rights \\
\hline
\end{tabular}

